Article

\title{
Subjunctive and Interpassive "Knowing" in the Surveillance Society
}

\author{
Sun-ha Hong \\ Annenberg School for Communication, University of Pennsylvania, Philadelphia, PA 19103, USA; \\ E-Mail: shong@asc.upenn.edu
}

Submitted: 7 April 2015 | Accepted: 17 June 2015 | Published: 30 September 2015

\begin{abstract}
The Snowden affair marked not a switch from ignorance to informed enlightenment, but a problematisation of knowing as a condition. What does it mean to know of a surveillance apparatus that recedes from your sensory experience at every turn? How do we mobilise that knowledge for opinion and action when its benefits and harms are only articulable in terms of future-forwarded "as if"s? If the extent, legality and efficacy of surveillance is allegedly proven in secrecy, what kind of knowledge can we be said to "possess"? This essay characterises such knowing as "world-building". We cobble together facts, claims, hypotheticals into a set of often speculative and deferred foundations for thought, opinion, feeling, action. Surveillance technology's recession from everyday life accentuates this process. Based on close analysis of the public mediated discourse on the Snowden affair, I offer two common patterns of such world-building or knowing. They are (1) subjunctivity, the conceit of "I cannot know, but I must act as if it is true"; (2) interpassivity, which says "I don't believe it/I am not affected, but someone else is (in my stead)".
\end{abstract}

\section{Keywords}

belief; experience; imagination; interpassivity; media; mythology; ritual; surveillance; technology; uncertainty

\section{Issue}

This article is part of the special issue "Surveillance: Critical Analysis and Current Challenges", edited by James Schwoch (Northwestern University, USA), John Laprise (Independent Researcher) and Ivory Mills (Northwestern University, USA).

(C) 2015 by the author; licensee Cogitatio (Lisbon, Portugal). This article is licensed under a Creative Commons Attribution 4.0 International License (CC BY).

\section{We Knew Already}

At least, that was what some people said after Edward Snowden's leaks on NSA surveillance. Did he tell us anything we didn't know?, asked journalists (Milner, 2013). "They didn't feel much like revelations", said a director (Laskow, 2013). But what was meant by this curious phrase, we knew already? "Knew"-yes, some of the information really was public knowledge. But even the entirely new aspects of it were, apparently, not very surprising. After all, the discourse goes, we already "knew" of older NSA programs like Trailblazer and ECHELON-so we surely expected something like PRISM. But who is this "we"? The discourse designates a depersonalised hivemind: the knowledge of NSA surveillance was stored in our collective archive, though the proof is in nonhuman documents rather than what individuals can "remember". Sometimes, the "we" instead designates the journalist, the director, the activist: the "we" in the know who pens these commentaries, the "we" that is less gullible than the average Joe, the "we" of the "we told you so". And what about the "already"? Despite itself, the discourse is less about defining past concerns and more about characterising the present. It is a way to designate a historicity for the revelationswhether to dampen the outrage or stoke it. So: this we sure isn't everyone, and sometimes excludes me at least; and the knowing it did certainly wasn't a very comprehensive one. Satire, as it so often does, brings these ambiguities into the open: "We already knew the NSA spies on us. We already know everything. Everything is boring" ("We already knew," 2015). What has knowing ever done for us, anyway?

These questions provoke and organise the present essay. I argue that what happened with Snowden was not a simple flip of the switch from collective ignorance to enlightenment. Rather, it is a question of 
what knowing involves. How do we develop belief about a surveillance system so vast it cannot be experienced by any single individual-and moreover, a surveillance system which consistently seeks to recede from lived experience? How is a "we"-thatknows interpellated, and how is this "knowledge" leveraged to authorise actions and opinions? It is often said that surveillance inherently violates our fundamental rights, and the public need only be informed in order to rise up against it. Others explain contemporary surveillance in terms of disempowerment, paranoia and anxiety (Andrejevic, 2013a; Bauman \& Lyon, 2013; Browne, 2010). Yet for all the merits of such criticism, they sit uneasily with the fact that most people have learned to live with their awareness of Orwellian surveillance. Whether one seeks to defend state surveillance or denounce it, the basic operation that underlies both is a "world-building". The facts and arguments are cobbled together to present a new intuition, a new common sense, about how this enormous technological apparatus runs our world. Hence the question: how do we develop a sense of contemporary surveillance as a world "out there"?

In what follows, I first describe the recession of surveillance practices from the subject's lived experience. The gap created by this recession accentuates the role of speculation and belief. I then offer a conceptualisation of world-building vis-à-vis surveillance, drawing especially from phenomenology, affect theory and ritual theory. Finally, I discuss two common patterns in the Snowden affair discourse to indicate particular techniques of world-building. They are (1) subjunctivity, the conceit of I cannot "know" but I must act "as if"; (2) interpassivity, which says I don't believe it/I am not affected, but someone else is (in my stead). These latter sections are based on ongoing research into the public discourse on the Snowden affair for a larger project. This essay draws on U.S. media coverage from June 6, 2013 (the date of the first leak) until March 14, 2014, focusing on prominent publications such as The New York Times and The Washington Post. ${ }^{1}$ It also draws on high-profile public statements, such as Edward Snowden's public appearances and statements by President Obama or NSA personnel. The essay's arguments arise from identification of the recession of surveillance, and techniques for coping with that recession, in this body of discourse.

${ }^{1}$ All relevant coverage from the following publications were examined: New Yorker, The Atlantic, The Intercept, The New York Times, The Washington Post, Wired (all online). The Guardian was also included as an especially relevant publication that was also read directly by many U.S. readers (which was not necessarily being true of Der Spiegel, another key player in the affair). Some snowballing was also conducted on the data for this essay.

\section{Recession}

People should be able to pick up the phone and call their family, should be able to send a text message to their loved ones, buy a book online, without worrying how this could look to a government possibly years in the future. (Edward Snowden in Rowan, 2014)

The irony is that many of us -including those outraged by NSA surveillance-do call our family, buy books online, and sleep very well at night. A few months after Snowden's appearance, a Pew survey (Rainie, Kiesler, Kang, \& Madden, 2013) suggested that the majority of Americans believe their privacy is not well protected by current laws. Yet in most cases, their response amounted to deleting cookies. If the gesture was hopelessly inadequate, it at least had the virtue of being convenient. This apparent contradiction arises from the recession of surveillance. In contrast to the flood of media reports, actual surveillance technologies systematically withdraw from our lived experience and "personal" knowability. The mantra for this situation: "I know they might be watching, Edward Snowden told me so-but I don't 'experience' it."

We can first of all characterise this recession as technological. In a basic sense, all technology involves a withdrawal from sensory experience. Heidegger's hammer externalises human action and intention, and embeds it in a crafted object (Scarry, 1985). Computational technology often amplifies this recessive character. The smooth surface of the smartphone, even compared to the gears and chains on a bicycle, encourages us to forget the connections, dependencies and processes that maintain our environment-and should we remember, denies us easy access to that knowledge (Berry, 2011, Chapter 5). This is precisely the case with contemporary online surveillance. It is designed to operate behind the front-end user interface, sweeping up personal data out of human awareness. It interacts with the world-and us - in ways that our senses cannot access. ${ }^{2}$ Even the physical databanks are literally isolated in a giant data centre in the Utah countryside. This is in distinct contrast to, say, American police surveillance. In that case, the post-1970's period has seen techniques like house raids, court summons, patrols, pat-downs and urine tests to impose state power viscerally upon the (especially poor black) population (Goffman, 2014). If in police raids or airport screenings (Adey, 2009; Parks, 2007; Schouten, 2014) surveillance intrudes rudely upon one's space, habit, affect and body programs like PRISM do the oppo-

\footnotetext{
2 In Mark Hansen's (and through him, Whitehead's) vocabulary, recession is a question of phenomenological access. Surveillance is not only hidden in a traditional sense (classified, made a state secret); the technology itself is designed to operate at a sub-experiential level. See Hansen, 2015.
} 
site. They evacuate every sign of their existence from lived experience. Consider the web beacon, commonly used in corporate/commercial surveillance. Also called tracking pixels, it is a tiny $(1 \times 1$ single pixel), transparent object embedded into web pages to track user access. It is literally invisible to the naked eye, and the user may only discover it by bringing up the source code. Of course, even if I am informed of the existence of beacons and how they work, I quickly realise that it is impractical to comb through the source code of every page I visit. Momentarily armed with the power of knowledge, I surrender it again in favour of a deferred and simulated feeling-knowing: "I would be able to tell if a beacon is tracking me if I took the time to look."

The beacon illustrates the recession's epistemological properties. The subject is distanced from knowledge of surveillance at multiple levels. There is what we might call, in Rumsfeldian terms (Hannah, 2010), a "known unknown": I know that I will never know if an NSA agent has gone through my metadata. Then, there is the "unknown unknown": Snowden has revealed programs like PRISM and XKeyscore, but given the apparently enormous quantities of documents in Snowden's hands, and given that Snowden himself won't know everything, I now know that I am unlikely to ever know what I don't know about my vulnerability to surveillance. In Kafka's The Trial, what strikes Josef $\mathrm{K}$. is not the fact that he is charged with serious crimes; it is that, despite every desperate attempt, the inscrutable bureaucracy yields no knowledge of what he is charged with and why. Certainly, Snowden's revelations have provided new information about state surveillance; "we" can say we "know" more than we had before. But we can see that this knowing can actually contribute to the recession of surveillance.

One ironic aspect of this recession is that most of us experience discourse about surveillance more than surveillance itself-a situation we also find with respect to globalisation (Cheah, 2008) and the nation-state (Anderson, 1991). Surveillance becomes available for talk and thought precisely as an estranged and phantasmal object. Through public, mediated discourse surrounding the Snowden affair, we make this surveillance into something knowable and sensible-even if the kinds of beliefs produced here are not strictly reducible to objective fact. This is what I mean by world-building activity. It is the interpellation of the surveillance society as a world "out there". Recession and world-building are intertwined. The former emphasises what we do not and cannot "know" for ourselves. The latter is how, despite this gap, we try to make some sense of the world we find ourselves in. Surveillance hides from us, but we cannot help but talk about it endlessly.

\section{The "Out There"}

Our ability to render surveillance society comprehensi- ble is predicated not (only) on objective proof and available facts, but conventionalised ways for putting what we know together with what we don't know; ways for forming a coherent, though often inconsistent, picture. As noted above, many Americansthrough media like Pew surveys-claim they are concerned about surveillance and often feel unsafe. At the same time, this same public has exhibited a clear willingness to live in and with this surveillance society, in many (not all) cases declining to take revolutionary or directly political action in response to the Snowden leaks. It is not sufficient to presume false consciousness, an illusory daze maintained by a clever concoction of ideology, misinformation and obfuscation. Studies into risk perception have shown that becoming better informed does not necessarily correlate to a stronger perception of dangers-or concrete actions taken to mitigate them (Douglas, 1992; Wildavsky \& Dake, 1990, pp. 31-32). A similar sentiment is now being expressed by surveillance and privacy scholars. Subjects can know very well their rights are being violated and live with that violation (Andrejevic, 2013b; Mansell, 2012; Turow, 2013). The key is not to seek to unravel this "contradiction" into a consistent explanation, one which would supply us with a "worldview" with a singular internal logic. Subjects, Lauren Berlant tells us, are surprisingly good at managing their affective incoherence and disorganisation, and defending it in their own terms (Berlant \& Edelman, 2014, p. 6; Berlant \& Greenwald, 2012). When my firm belief in control over my life is challenged by news of state surveillance, or when my habituated attachment to new media bristles against my political views, I do not always respond with bold and sweeping changes to smooth out the differences. Rational consistency is often not our highest priority. Instead, what emerges is a set of platitudes, "common sense" wisdoms, habits, turns of phrase, speculative beliefs, recited facts, which support precisely the contradictions I have already come to embody. Now, this line of thought must be distinguished from older modernist denigrations of "primitive" beliefs. Those were presumed to be an amalgamation of non-scientific mistakes taken as eternal truths-thus explaining their resistance to rationalist "demystification". Here, it is a question of making knowledge of the world work for what subjects can't help but know, face, and deal with in their present lives. In short, to study world-building activity vis-à-vis surveillance is to understand how we cope (Berlant, 2011) with our own persistent living while under exposure to a relentless program of observation.

This isn't to say that nothing can knock us off from our serene perch. Crises happen-sometimes erupting in political and psychological drama, sometimes undoing social cohesion or individual well-being quietly in the backstage. Surveillance, too, can sometimes confront subjects violently and threateningly. The world- 
building perspective is to explain how things "work" not perfectly, but sufficiently-in those times when crises don't happen, or when (possible) crises become dampened into compromises and apologies. The Snowden leaks certainly did challenge our previously built worlds. For some, it really was a crisis, driving them to explicit changes in behaviour. But many subjects also found ways to restore normalcy precisely by responding to new narratives and events, and rebuilding their positionality vis-à-vis the world out there. That is what we have always done, after all-even back when "we knew already". A great deal of knowledge about U.S. state surveillance had been available to the public before 2013. But this "we" had stumbled on ways to keep that knowledge sequestered in a dusty corner, a largely negligible and rather conspiratorial fact about "politics these days".

What these world-building responses suggest is that we have multiple ways of "knowing" and "believing". Indeed, those very terms do not do justice to that multiplicity. What does it mean to "know" when a teenager says "I know what I learned in school today", but can't articulate it to the expectant parent? What does it mean to "believe" in God but nevertheless demand scientific proof of his existence-or, inversely, accomplish my "belief" by submitting to Pascal's wager? As Žižek might quip, we know many "truths", but truths we are willing to die for, which we believe in absolutely in any circumstance, are all too rare. This is easier for us to grasp when we consider a nonmodern case. The Dorzé people in Ethiopia believe leopards are also Coptic Christian and observe fasting days prescribed by the religion....and on those fasting days, they will take care to protect their livestock from hungry leopards, as they've always done (Veyne, 1998, pp. xixii). They see nothing strange in this. Similar cases abound in anthropological writings. The Nuer believe twins are birds, which is distinct from saying birds are twins or that this twin is a bird (Douglas, 2001, p. 148). The key is to take on such contradictions not as mistakes or ignorance but as genuine world-building techniques. Or again: Merleau-Ponty (2012) argues that mythology or madness is not a case where our objective connectivity with the material world is underdeveloped or broken. Rather, a mythological explanation or a schizophrenic's hallucinations, for those subjects, involve a way of perceiving and understanding the world that is just as intuitive and genuine as our relationship to science, visual phenomena or speech. A schizophrenic woman believes two people with similar looking faces must know each other (Merleau-Ponty, 2012, pp. 298-299). This is an abnormal wiring of world-building capacity, but one which makes life possible and sensible for this woman in the same way something like physiognomy did normatively for $19^{\text {th }}$ century urban dwellers (Pearl, 2010). The normal is full of arbitrary connections, too; one example is confabulation, or the pre-reflective and non-deliberate fabrication of personal memory that appears to occur in spontaneous ways to achieve self-understanding of what just happened (Orulv \& Hyden, 2006).

In short, not only are our worldviews often complex and contradictory, we are also able to hold a plurality of relationships to the world out there through these flexible ways of knowing and believing. Why do we do this? Because contradiction and even incoherence can often be of great use in our ordinary living. Sometimes it's a matter of convenience, or of persuading others (and myself), of saving face. Sometimes we persist in some kind of belief because to jettison it would change our own image of ourselves unacceptably. The "effect" of a truth or belief is thus entangled with its "cause". To accuse such activity of inauthenticity is to miss the point. Such multiplicity is often critical to our ability to cope with our lived reality. It is what gives the subject the power to stay cohesive across the battery of situations and challenges it faces each day and hour-to maintain a feeling that despite everything, the world continues to make some minimal sense.

The next two sections will discuss concrete ways in which such world-building is taking place in the wake of the Snowden affair. They analyse how public debate is producing various narratives of the new surveillance world, and importantly, what specific ways of knowing and believing are involved in such production. The mass media plays what we might call a ritualistic role in this process. Media has been classified as ritualistic in the sense that media activity itself is often calendrical and collectively coordinated for effects of "liveness" and participation (Dayan \& Katz, 1992). This effect is not reducible to the symbolic content of media coverage. Even if not everyone watches the same television program, even if interpretations of specific messages differ, even if some may not take media reports of the dangers of surveillance seriously, mass media have a phatic effect. The rhythmic pattern with which they take a place in our everyday life produces in itself a sense of connectivity to a wider world (Frosh, 2011). This phenomenological relationship enjoins the public not to swallow whatever they are told by the television anchor, but to continually adjust their positionsceptical, believing, critical, supportive-relative to media representations (Carey, 1975). It is on this basis that media performs itself as a "centre" of society, one which provides "transcendent patterns within which the details of social life make sense" (Couldry, 2003, p. 3). In other words, the media is less an indisputable source of factual statements about the world, than it is a repository of themes, topics and interests against which we form our beliefs about how the world works. One might decry surveillance coverage in the media as conspiratorial nonsense (of the Left, of the Right, of the American government, or the Russian one...) and disbelieve it; but that very move often entails trusting that coverage as 
some reflection of what "people out there" believe.

This leads back to the "we" of "we knew already". Insofar as my sense of the surveillance world is framed in relation to what I believe is the public understanding and experience of surveillance, the public "out there" becomes an essential part of this mediated worldbuilding. Indeed, the modern public, from its very inception in the age of the printing press, has always had a virtual and imagined quality. After all, what I can see and hear on my own is always only a small part of that human multitude, one which extends into the "out there" as an indefinite set of strangers (Eisenstein, 1980; Tarde, 1969; Warner, 2002). We learn to authorise ourselves to speak on the public's behalf, or at least, presume what the public thinks and knows, in order to produce our own positions (Bourdieu, 1979; Hong, 2014). Media discourse, insofar as it is a ritualised promise of a "centre" of society, instructs its audience not only on what the public allegedly is, but how to relate to the public as an object of knowledge and belief (Fraser, 2006, pp. 155-156). Media discourse is thus the site where multiple ways of knowing and believing are expressed and legitimated, and it is on this basis that we are able to build a sense of surveillance as the world "out there". We now move to two specific patterns: subjunctivity and interpassivity.

\section{Subjunctivity}

Your rights matter because you never know when you're going to need them. People should be able to pick up the phone and call their family, should be able to send a text message to their loved one, buy a book online, without worrying how this could look to a government possibly years in the future. (Snowden in Rowan, 2014)

I buy fire insurance ever since I retired, the wife and I bought a house out here and we buy fire insurance every year. Never had a fire. But I am not gonna quit buying my fire insurance, same kind of thing. (James Clapper in Lake, 2014)

"You never know" is the ominous mantra that grounds both the claims of Edward Snowden, whistleblower, and of James Clapper, the U.S. Director of National Intelligence. "You never know" invokes a looming: a threat that is nothing yet, but is very much real in its existence as potential (Massumi, 2005, p. 35). The Orwellian future where you might be punished for your ordinary actions today; the apocalyptic scenario when terrorism happens to you and your family. That which by definition cannot ever be made certain is invoked as presumptively real in order to legitimise actionwhether for or against state surveillance.

This is the as-if, the subjunctive. Grammatically, the subjunctive mood is the flotation of a non-true state- ment: "if I were..." This very construction produces an ambiguity, a split construction of "belief". Such constructions sustain a state of affairs which is neither mere illusion nor fully believed to be true. In the Snowden discourse, we find the paradigmatic formulation of subjunctivity to be the as if: we must act, think, feel, believe, as if I am personally under watch, as if terrorism is about to happen to me, as if surveillance does help us prevent terrorism. In other words, the subjunctive involves a two-pronged handling of knowledge and belief, and this very ambiguity is what lets us leverage the unknown: "Yes, we don't know if it's true or not, but we have to pretend it is true". It is telling that one of the few scholarly fields where subjunctivity is commonly discussed is in science fiction studies, centred on the work of Samuel R. Delany (1971). Although deployments of subjunctivity do not materially count as "events", these characteristics mark them as highly ritualistic. Rituals have been called "time out of time" (Rappaport, 1999, pp. 216-222). They are moments when we collectively say, wait: let us step out of our rules and rhythms of life for a moment, so that they may be renewed and reaffirmed, or even, adjusted with localised change (such as the change in status of an individual member in a rite of passage). Similarly, the as-if is a way to step into a liminal (Turner, 1982) zone in one's thinking and believing, but one which is then sutured back into one's assessment of "reality". It is a way for us to deal with our ignorance, our uncertainty, and other ways in which our present and ourselves in that present disappoint us. It is a way to cope with the imperfections and vulnerabilities of our exposure to power and danger.

This subjunctive turn in surveillance has been subject to much commentary. In risk literature, it is described in terms of "precautionary" or "catastrophic" risk-enormous uncertainties of climate change and terrorism which outstrip the industrial risks of factory disasters and chemical contaminations (Aradau \& van Munster, 2007; Ewald, 1993). Surveillance studies frequently references Brian Massumi's (2007) pre-emptive logic: a radicalisation of traditional causality and proof in a world of pure potentiality. My account does not necessarily supplant or contradict these theorisations. Rather, it emphasises the world-making aspects of subjunctive logic; a world-making which is capable of supporting both pro- and anti-surveillance attitudes.

The first type of as-if that permeates our present relationship to surveillance is the uncertainty about whether I am being watched at all. This effect is created by the juxtaposition of an apparently enormous and pervasive surveillance system, and, given its recession, the fact that the surveilled subject will rarely know if they have ever been "watched" by a human agent. Surveillance becomes a Deleuzian virtual. For Snowden and other opponents of NSA surveillance, it is critical to overcome this felt recession if the public is to "build" a 
world where surveillance is a keen danger. Ironically, this task is undertaken by combating another kind of as-if. Anti-NSA discourse consistently interpellate an imagined public, one which presumably thinks it is safe as long as it has not done anything "wrong". A New York Times opdoc, "Why Care About the N.S.A.?" opens thus:

Narrator: I want to get your response to a few things people typically say who aren't concerned about recent surveillance revelations.

David Sirota: Nobody is looking at my stuff anyway, so I don't care? My argument for that is if you don't speak up for everybody's rights, you better be ready for your own rights to be trampled when you least expect it. First and foremost, there are so many laws on the books, there are so many statutes out there, that you actually probably are doing something wrong....So when you start saying I'm not doing anything wrong...you better be really sure of that. (Knappenberger, 2013)

Sirota's warning is accompanied by a dizzying array of legalese in flight (Figure 1). By shifting the subject's gaze onto the bureaucratic and technological depths which almost entirely lie beyond everyday experience, the subject is divested of the ability to confirm or deny his/her own safety. This is distinct from the simple claim that we are not safe. It is (also) the claim that we do not have the ability or resources to tell in the first place. The projected "common sensical" subject is appealed to through an indeterminate "what if" situation, and implicitly, the argument is made that since the "what if" is particularly unsavoury, it should be considered as an "as if". Thus the reality of surveillance is impressed upon the subject not by recovering concrete surveillance practices from their recession, but actually by expanding their virtual dimension into an enormous, totalitarian as-if. Snowden and his sympathisers argue they are informing the public. True. But what they are also doing, above and beyond that, is to modulate an imagination which is necessarily in excess of the information strictly available.

This same technique is applied to the objective of surveillance itself: the threat of crime, and especially of terrorism. James Clapper quips that PRISM is no different from fire insurance. But insurance developed its appeal by quantifying fearful indeterminacy into percentages and premiums. The strategic use of disaster statistics and risk percentages could claim to provide a stable and objectively factual knowledge of danger and vulnerability. This is decidedly not the case with post9/11 surveillance (Beck, 2009; Ewald, 1993). Terrorist attacks are sometimes analysed statistically, but their relative scarcity makes it difficult to draw convincing conclusions. The danger of being surveilled or falling victim to a terrorist attack is generally not parsed in terms of estimable "risks" (at least, not in public debate). As has been extensively analysed (and criticised), U.S. surveillance and anti-terror policy following September 11 has been predicated on the idea that even one attack is too much, and even one percentage a chance is too great (Aradau \& van Munster, 2007; Cooper, 2006; Hannah, 2010). The proponents of state surveillance thus rely on the same "excessive" designation of the as-if. One key metaphor for NSA surveillance programs has been the dragnet, traditionally used to describe police activities like location-wide stop and frisks. The dragnet indiscriminately collects data on the innocent as well as the suspicious, highly relevant data as well as irrelevant ones-because the innocent can always turn out to be the criminal, and the most irrelevant piece of data may help triangulate his/her identity.

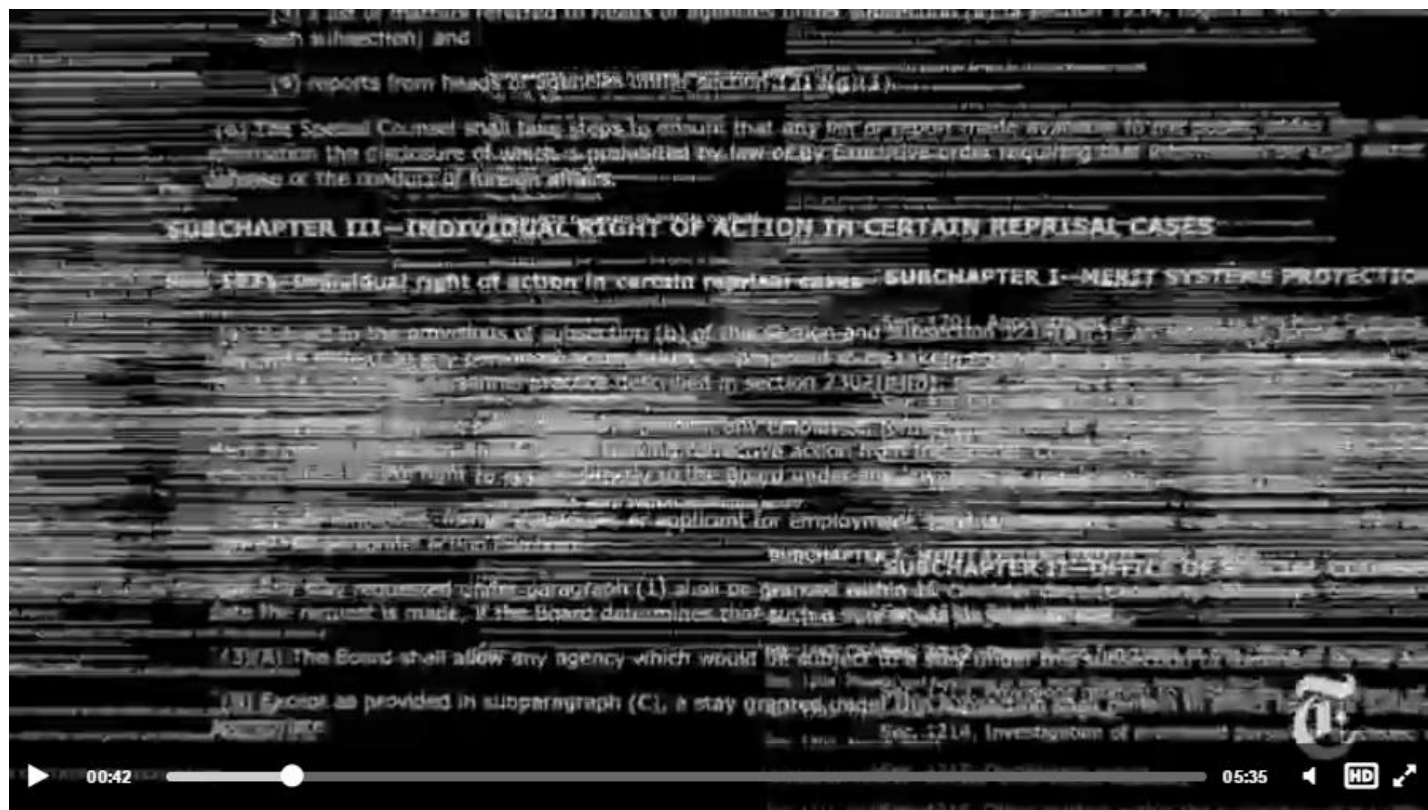

Figure 1. "Why care about the NSA?" 
Within this rationality, surveillance is not, strictly speaking, proven to be necessary by past terror attacks or present identification of concrete dangers. Proof is always deferred: we must act as if the efficacy of this program has been proven by a danger which, if we are right, we will prevent from ever actualising.

Subjunctivity is one name for how public figures present the world of surveillance. Importantly, this presentation is also a part of public subjects' wider, lived relationship to that complicated and distant world. And crucially, our relationship to the media discourse on surveillance itself becomes subjunctive as we try to navigate this tangle of complex and often contradictory claims. How can we produce a picture that makes sufficient sense to us, and how can we say to ourselves that we "know enough" to act, to not act, or at least to have an opinion about the whole affair? For instance, the subject's ability to assess the legality of surveillance becomes challenged by his/her experience of this discourse. Snowden's revelations were, at least, generally accepted in the media as solid, reliable information about the technical process of NSA surveillance. However, the precise legality of each given practice, and indeed, the question of who actually knows about and guarantees each practice, is explicitly designated as uncertain. As one headline put it: "You'll Never Know if the NSA Is Breaking the Law" (Bump, 2013). On one level, as David Sirota did above, it is suggested that there are so many different programs, legal decisions, secret courts and procedures involved, the public as a whole will "always" be left uncertain as to if the letter of the law is really being broken. On another level, we cannot presume that the reading public is a homogeneous mind with full access to every piece of information made available to them. The "we" of "we knew already" does not exist in such a form. Most subjects are likely to experience a partial picture, based on their limited reading and recall, of conflicting arguments and claims made in public. One may not keep up with every Snowden leak, tell apart XKeyscore from PRISM, or even understand exactly what counts as metadata and what doesn't. But it is more than possible to take away a general picture: the idea that the legality of surveillance is uncertain, and that any opinion or action we take will have to happen in abeyance of that knowledge.

What these situations suggest is that information often begets uncertainty, and in turn, provokes subjunctive responsivities. It is indisputable that Snowden's leaks have increased the total amount of knowledge we collectively hold about NSA surveillance. But the more Snowden reveals, the more cause we have for paranoia and uncertainty-an ironic reversal of Shannon's law of information. When we learn that the NSA monitors video game chatter for terrorist activity (Ball, 2013), it does not provide reassurance that we now know everything there is to know about that sordid affair. Rather, it gives us license to believe that if such a thing is true, surely many more things might be as well. Table 1 lists only the major additions to "our" knowledge of NSA surveillance between June 2013 and March 2014. It is quantitatively beyond what most subjects can afford to give full attention to. Indeed, the sheer number of documents Snowden has been said to possess -1.7 million by one count (Kelley, 2013)-makes the Snowden files themselves an inexhaustible and virtual repository of new revelations, just like the NSA's portfolio of surveillance technologies or the manifold dangers of the post-9/11 world. As with the question of legality, many subjects proceed with a general awareness that there is a plethora of leaks, without a firm grip on each leak or what they concretely add up to. Mary Douglas once asked: why do experts insist on educating the public about issues like climate change? Don't they realise that the more information becomes available, the more possible interpretations arise, and the more intractable a sensitive topic becomes? (2001, p. 146) To this, we might add: don't they know that information can feed speculation, rather than extinguish it? The Snowden leaks have provided additional ingredients for feeling uncertain and vulnerable. Whatever political position (including apathy and a "wait-and-see" prudence) one chooses, whatever imagination of surveillance one subscribes to, it must be predicated on an uncertain and receded reality that one chooses to overcome through the "as-if".

Finally, the subjunctive experience even extends to cases where subjects do try and take concrete steps to protect themselves from surveillance. While Edward Snowden espouses the benefits of programs like TOR, he admits:

You will still be vulnerable to targeted surveillance. If there is a warrant against you if the NSA is after you they are still going to get you. But mass surveillance that is untargeted and collect-it-all approach you will be much safer [with these basic steps]. (“Edward Snowden SXSW," 2014)

Nearly every privacy solution recommended today comes with such caveats. As the concerned public flocked to existing privacy solutions, one VPN (Virtual Private Network) developer-a common alternative to TOR-commented:

If you're concerned about surveillance agencies such as the NSA, their capabilities are shrouded in secrecy and claiming to be able to protect you is offering you nothing but speculation. (Renkema, 2014) 
Table 1. Major revelations on NSA surveillance, June 2013-March 2014.

\begin{tabular}{|c|c|}
\hline 14.3.12 & Leak: NSA “Expert System” for malware implants allegedly planned \\
\hline 14.2.10 & Leak: NSA metadata \& geolocation helps drone attack \\
\hline 14.1.27 & Leak: NSA uses "leaky” mobile apps \\
\hline 14.1.16 & Leak: NSA collects millions of texts \\
\hline 13.12.13 & Leak: NSA cracks cell phone encryption for A5/1 (2G standard) \\
\hline 13.12 .10 & Leak: NSA uses cookies to spy \\
\hline 13.12 .9 & Leak: NSA uses video games to spy \\
\hline 13.12.4 & Leak: NSA collects 5 billion phone records per day \\
\hline 13.11.26 & Leak: NSA spies on porn habits \\
\hline 13.11.23 & Leak: NSA “Computer Network Exploitation" infects 50k networks \\
\hline 13.11.14 & Leak: $\mathrm{CIA}$ collects bulk international money transfers \\
\hline 13.10.31 & Leak: NSA hid spy equipment at embassies \& consulates \\
\hline 13.10.30 & Leak: NSA attacks Google \& Yahoo data centres \\
\hline 13.10.24 & Leak: NSA tapped 35 world leader calls \\
\hline 13.10.21 & Leak: NSA spied on Mexico's Calderon, emails \\
\hline 13.10.14 & Leak: NSA collects US address books, buddy lists \\
\hline 13.10 .4 & Leak: NSA can hack Tor \\
\hline 13.10.2 & Leak: NSA stores cell phone locations up to 2 years \\
\hline 13.9.30 & Leak: NSA stores metadata up to a year \\
\hline 13.9.28 & Leak: NSA maps Americans" social contacts \\
\hline 13.9.16 & Leak: NSA "Follow the Money" division tracks credit card transactions \\
\hline 13.9.7 & Leak: NSA can tap into smartphone data \\
\hline 13.9 .5 & Leak: NSA attacks encryption standards and hacks \\
\hline 13.8 .29 & Leak: US intelligence "black budget" \\
\hline 13.8 .23 & Leak: NSA employees spy on ex-lovers \\
\hline 13.8 .15 & Leak: NSA internal audit shows thousands of violations \\
\hline 13.7.11 & Leak: XKEYSCORE program. \\
\hline 13.7.10 & Leak: NSA “Upstream” fibreoptic spying capacities \\
\hline 13.6.30 & Additional PRISM leaks \\
\hline 13.6.19 & Leak: NSA “Project Chess" for Skype \\
\hline 13.6.17 & Apple, Microsoft, Facebook release details \\
\hline 13.6.16 & Leak: NSA spied on Medvedev at G20, 2009 \\
\hline 13.6.11 & Leak: BOUNDLESS INFORMANT for surveillance records globally \\
\hline 13.6.10 & Snowden named \\
\hline 13.6 .9 & Leak: NSA record/analysis tool \\
\hline 13.6.7 & Leak: "Presidential Policy Directive 20 " for cyberattacks to foreign targets \\
\hline 13.6.6 & Leak: PRISM revealed \\
\hline
\end{tabular}

In other words, the subject's feeling safe enough is predicated on his/her ability to live on as if whatever tools chosen (including none) has provided sufficient protection against this unknown and silent risk. After all, one will never know if one's privacy was in fact compromised. The lived experience of interacting with privacy tools also contributes to this subjunctive situation. Consider AVG PrivacyFix (Figure 2), one of many simpler tools which promise to protect against (in this case, corporate) surveillance. It is all too easy: a few clicks, yellow and white symbols flashing into a reassuring green, and one is allegedly safer. Certainly, some of this software at least does provide some real mitigation against major surveillance techniques. But for any subject that is not particularly well informed or technologically savvy, the experience of using these programs is often a simulation of safety: a simulation against the inscrutable backdrop of a receded world. And so, even the subject who does "everything possible" to guard against surveillance must subjunctively reassure him/herself that "everything possible has probably been done".

The as-if is a technique for leveraging the receded, virtual enormity of "surveillance" to a produce a presumptive basis for knowing and believing. Such knowledge or belief is ambiguous and complex. One acknowledges the probabilistic or speculative nature of one's own belief, but simultaneously applies a practical-and sometimes even moral-injunction that hardens this belief and qualifies it for speech and action. 


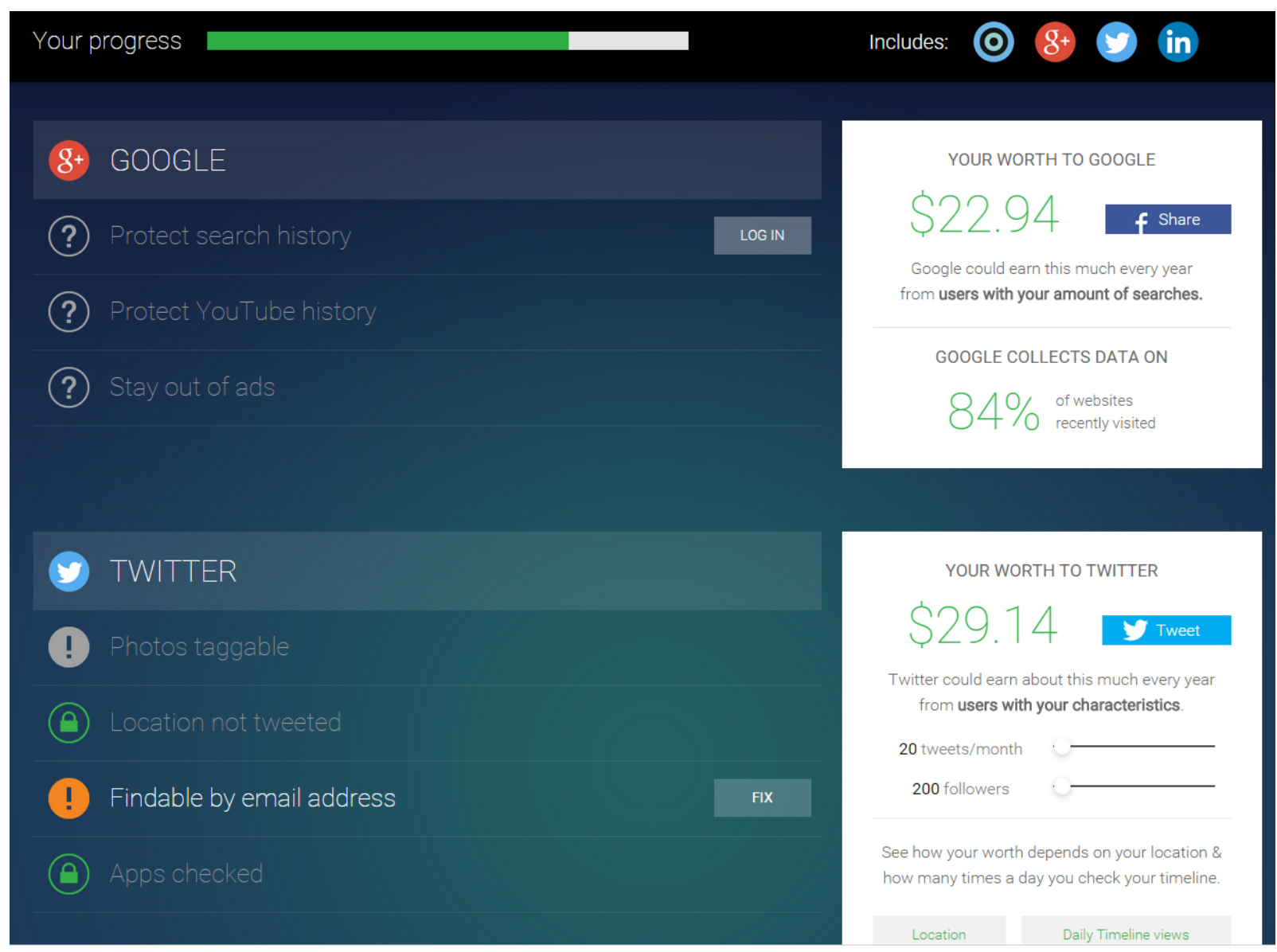

Figure 2. AVG PrivacyFix user interface.

\section{Interpassivity}

Interpassivity originally arose from art and media theory as a response to the dominion of "interactivity" (Pfaller, 2003; Scholzel, 2014; Van Oenen, 2002). It is now applicable as a more general conceit: "not me, but another for me". Someone else believes, so that even if I do not, it remains a kind of "truth" (Žižek, n.d.). I Xerox a book or VCR a television show, and become satisfied that I have nearly consumed it; in a way, the machine has "watched it for me" (Pfaller, 2003). This deferral, this "outsourcing" (Van Oenen, 2002), has numerous practical uses. Interpassivity allows us to maintain beliefs which may not be supported by our own behaviour, identity and environment. I don't believe Obama is Muslim, but there are people who do. I don't find this content morally offensive, but other people might. In such cases, the interpassive articulation excuses the subject from being bound to the belief in question, even as that belief is hypostatised into reality, thereby forming a reliable basis for opinions and actions. Indeed, in some cases, "delegating one's beliefs makes them stronger than before" (Pfaller, 2001, p. 37): my beliefs now appear as objective fact, something I cannot dismiss as mere flight of my fancy. We are familiar with this mechanism, of course, in the work of rumour. The conceit "I have heard it said elsewhere" holds the truthfulness of the rumour in con- stant suspense, adding to its resilience. I cannot vanquish a speaker who is there in absentia.

It is critical to understand what kind of "belief" is at stake in an interpassive movement. When I "act as if the Xerox machine were reading the text [for me]" (Pfaller, 2003), clearly, I do not "literally" believe that I have read the book. But I may well derive satisfaction from the act; a satisfaction that says "it is almost as if I have read the book, since I can now read it at any time I choose." When canned laughter laughs "for me" in a television sitcom, I do not look back and say "I now need not laugh." But, as Žižek (n.d.) points out, the experience can often leave me feeling "relieved" and rested afterwards. Such satisfaction is not necessarily reducible to false consciousness or pathological misrecognition. Interpassive techniques are ways for subjects to navigate a world which is so often alien to them, a world which they must nevertheless and constantly articulate as sensible and reliable. We employ interpassivity on a daily basis because it is a way to cobble together some understanding of politics, technology, public opinion, in the face of the harsh fact that so much of it exceeds our own experience and environment. The very ability to believe in surveillance as a part of our world is predicated on some noncongruence, some difference, between my "here" and the "out there".

Interpassivity was commonly leveraged in the 
Snowden affair to mitigate precisely the recession of surveillance practices and knowledge from public debate. Indeed, certain "knowns" were quite explicitly evacuated out of the public domain and designated as "known elsewhere":

Here's the rub: the instances where [NSA surveillance] has produced good-has disrupted plots, prevented terrorist attacks, is all classified, that's what's so hard about this. (Dianne Feinstein in Knowlton, 2013)

Feinstein and others insisted that the fruits of surveillance could not be proven publicly, lest that too endanger national security. Although one or two concrete cases have been mentioned (such as Najibullah Zazi's 2009 plot), the general trend was to claim that proof, too, was classified for the sake of security. Notably, these claims do not simply place the public in ignorance of "all the facts"; they demand that public deliberation take place in full awareness of that ignorance. It becomes impossible to simply say "the benefits of surveillance have not been proven", since proof has been publicly designated as existing elsewhere. Feinstein's apology asks the reading public to actively hold their judgment in abeyance, or to be precise, make their judgment by simulating what someone else knows in their stead. All this is compounded by admissions that even the special court tasked to know in our stead-a court that is itself secret-also judges in ignorance. Reggie Walton, the presiding judge of that very court at the time, explains:

The FISC [Foreign Intelligence Surveillance Court] is forced to rely upon the accuracy of the information that is provided to the Court...the FISC does not have the capacity to investigate issues of noncompliance, and in that respect the FISC is in the same position as any other court when it comes to enforcing [government] compliance with its orders. (Leonnig, 2013)

The public is thus deprived of even the comforting thought that the law or the government "knows" in its stead. Rather, it is an indistinct other, dispersed and elusive, which promises to guarantee that surveillance indeed has been proven. This makes the interpassive movement fragile and speculative. When expert knowledge is stably instituted, the public can feel that it may reliably defer the work of knowing to those experts, and build a sensible world out of what the public itself does not know (Beck, 1992; Giddens, 1990). When expertise itself is threatened, as in climate change or the Snowden affair, the subject must make sense of what is happening in a more speculative and, indeed, subjunctive manner: "I don't know what the proof is, but if we presume for a minute that the proof is..." Even a cynical stance, which assumes that Fein- stein and others are lying and there is no proof at all, requires some presumptive position to be taken against the knowledge that another has "for" me.

Certainly, the subject is not always forced to pretend to some knowledge of surveillance, interpassive or not. Nina Eliasoph's ethnography of Americans' everyday discussion of politics describes communities which consistently shy away from talking politics. When Eliasoph herself brought such topics up, it was seen as "an inert, distant, impersonal realm" too hard to get a handle on. It was a shame that political problems happened, and the "public" should do something about it-but that "public", the people who ostensibly knew enough to debate the problem, were not them (Eliasoph, 1998, pp. 131-135). Even the refusal to have an opinion was qualified by the interpellation of an other who participates in publics in my stead. The recourse to interpassivity is not reducible to voluntary "choice" by an autonomous agent. It is a responsivity demanded by a situation - a situation which comprises of the recession of surveillance, including the logic of secrecy and security folded into the debate.

Not only can the other know for me, but they can also do and experience for me. Since surveillance's pervasiveness far outstrips the highly infrequent occasions on which it intrudes tangibly into individual lives, interpassivity becomes a key technique by which a given political and affective orientation becomes fleshed out into our reality:

My older, conservative neighbour quickly insisted that collecting this metadata thing she had heard about on Fox was necessary to protect her from all the terrorists out here in suburbia. She then vehemently disagreed that it was okay for President Obama to know whom she called and when, from where to where and for how long, or for him to know who those people called and when, and so forth. (Van Buren, 2013)

One might read this as typical liberal snarkiness about the cognitive dissonance of a stubborn conservative. But the general sentiment that there are people out there, "bad things" happening out there, that need to be watched and stopped is far from an abnormal one. Hence my own feeling of safety, my own ability to imagine a safer world, arises from a situation where someone else is surveilling someone else-myself, not being "that kind of person", one degree removed from the whole unpleasant affair. Indeed, interpassivity does not stop at projecting "probable factual events"; it also leverages downright fictional others. The non-news, fictional media thus participate in the ritualistic function:

Great Britain's George Orwell warned us of the danger of this kind of information. The types of collection in the book-microphones and video cam- 
eras, TVs that watch us-are nothing compared to what we have available today. We have sensors in our pockets that track us everywhere we go. (Edward Snowden in "Whistleblower Edward Snowden gives,"2013)

Snowden's comparison might have been a little redundant. Sales of Orwell's 1984 had already rocketed by some $6,000 \%$ after his initial leaks in June (Hendrix, 2013). Of course, one cannot claim that the public flocked to Orwell, Dick and Huxley in order to take them literally as prophecy. But such fictional work clearly served as resources for making sense of the confused present and the uncertain future. Some of this imaginative media also intersected the contemporary surveillance debate with an older tradition of representing crime and police work. Jonathan Nolan's Person of Interest debuted in U.S. television in 2011, two years before the Snowden leaks. The series was nevertheless conceived through extensive consultation of U.S. state surveillance practices as was known and estimated at the time (Gan, 2013). The popular series presented the public with an NSA-style dragnet which "spies on you every hour of every day", which the protagonist would use each episode to track down individuals before they became perpetrators or victims of violent crime. On one hand, "The Machine", Person of Interest's mass surveillance program, is clearly based on and evocative of U.S. state surveillance, providing the public with a simulation of hypotheticals. On the other hand, its show structure necessarily produces a world where urban crime of every kind proliferates and may strike any individual without notice. George Gerbner's famous cultivation theory suggested that media can have long-term, sedimented effects-that it can train people into presuming phenomena that lie beyond their own lives in order to, say, develop a heightened fear of criminal victimisation. This is not to say that Person of Interest is alarmist. The point is that insofar as terror and crime are not everyday realities for many (not all) of the population, we turn to fictional as well as strictly journalistic representations to develop an idea of what we can only assume is happening "out there". Nobody believes a television show is objectively true. But we often do leverage it for our world-building-just as we leverage the presumed opinions and actions of "others", and just as we leverage facts and statements we do not fully believe and cannot quite confirm.

\section{Feeling-Knowing}

Contemporary online surveillance is one which recedes in multiple ways from lived experience. This recession accentuates surveillance society's quality as a world out there: a vast, virtual entity which constantly eludes our knowing and living. Yet it is something which we invest a great deal of belief and passion into, cobbling what we know and suspect into a picture of a sensible, working world. The mediated public discourse on the Snowden affair exhibits two major techniques of such world-building. First, it leverages the virtuality and unknowability of surveillance as if it were in some way true and certain, producing hypothetical, provisionary bases for real, enduring actions and beliefs. Second, it encourages the notion that if not me, then another will know, experience, do in my stead. Even if the world of surveillance and terror is not real in my back yard, these interpellated others will make it real enough for me. The idea of the "public" or "society" provides a vast landscape of deferrals and potentials, a protective ambiguity for my political beliefs.

We began with a rhetorical question: "we knew already", didn't we? Well, what has knowing ever done for us, anyway? What matters at least as much as what we know or not, is what kind of knowing and believing has allowed us to engage that information. It is about what, affectively and epistemologically, it means to say 'I know'. Much has been made of the secrecy that surrounds state surveillance-the arcana imperii-and even corporate data-mining operations. The debate over Snowden as hero or traitor also revolves around this opposition of secrecy and transparency. Scholarly commentary often laments the ambiguous, uncertain and impoverished kinds of information the public is offered about surveillance. All of this is undoubtedly significant. But what this essay suggests is that we must also understand what techniques, what habits, of knowing and believing proliferate and become legitimated in this political environment. What wirings of narrative arcs, tropes, stereotypes, emotive associations, come into play in the discourse, images and practices of the surveillance society? It cannot simply be unrestrained paranoia or dangerousness. We use these symbolic ingredients not only to become afraid or suspicious, but also to cope with our subjection to surveillance, to make our daily routines and affects still make sense in this new world order. This line of questioning asks not what we know, but how we come to feel we know. And ultimately, it asks whether, given different circumstances, we could have a different relationship to knowing and believing surveillance.

\section{Acknowledgements}

The author would like to thank Carolyn Marvin, the anonymous reviewers, and the journal editors and staff at Media and Communication.

\section{Conflict of Interest}

This research received no specific grant from any funding agency. The author declares no conflict of interest owing to funding, employment or institutional membership. 


\section{References}

Adey, P. (2009). Facing airport security: Affect, biopolitics, and the preemptive securitisation of the mobile body. Environment and Planning D: Society and Space, 27(2), 274-295.

Anderson, B. R. (1991). Imagined communities: Reflections on the origin and spread of nationalism (Revised an.). London: Verso.

Andrejevic, M. (2013a). InfoGlut: How too much information is changing the way we think and know. New York: Routledge.

Andrejevic, M. (2013b). What we talk about when we talk about privacy. Paper presented at International Communication Association 2013, London, UK.

Aradau, C., \& van Munster, R. (2007). Governing terrorism through risk: Taking precautions, (un)knowing the future. European Journal of International Relations, 13(1), 89-115.

Ball, J. (2013, December 9). Xbox Live among game services targeted by US and UK spy agencies. The Guardian. Retrieved from http://www.theguardian. com/world/2013/dec/09/nsa-spies-online-gamesworld-warcraft-second-life

Bauman, Z., \& Lyon, D. (2013). Liquid surveillance: A conversation. Cambridge: Polity.

Beck, U. (1992). Risk society: Towards a new modernity. London: SAGE.

Beck, U. (2009). World at risk. Malden: Polity Press.

Berlant, L. (2011). Cruel optimism. Durham: Duke University Press.

Berlant, L., \& Greenwald, J. (2012). Affect in the end times: A conversation with Lauren Berlant. Qui Parle: Critical Humanities and Social Sciences, 20(2), 71-89.

Berlant, L., \& Edelman, L. (2014). Sex, or the unbearable. Durham: Duke University Press.

Berry, D. M. (2011). The philosophy of software: Code and mediation in the digital age. Basingstoke: Palgrave Macmillan.

Bourdieu, P. (1979). Public opinion does not exist. In A. Mattelart \& S. Siegelaub (Eds.), Communication and Class Struggle: I. Capitalism, Imperialism (pp. 124129). New York: International General.

Browne, S. (2010). Digital epidermalization: Race, identity and biometrics. Critical Sociology, 36(1), 131150.

Bump, P. (2013, June 28). You'll never know if the NSA is breaking the law - or keeping you safe. The Atlantic. Retrieved from http://www.thewire.com/ politics/2013/06/nsa-surveillance-legal/66681/

Carey, J. (1975). A cultural approach to communication. Culture and Communication, 2(1), 1-22.

Cheah, P. (2008). Cheah Pheng literature what is a world? On world as world-making activity. Daedalus, 137(3), 26-38.

Cooper, M. (2006). Pre-empting Emergence: The Bio- logical Turn in the War on Terror. Theory, Culture \& Society, 23(4), 113-135.

Couldry, N. (2003). Media rituals: A critical approach. Abingdon: Routledge.

Dayan, D., \& Katz, E. (1992). Media events: The live broadcasting of history. Cambridge: Harvard University Press.

Delany, S. R. (1971). About five thousand one hundred and seventy five words. In T. D. Clareson (Ed.), Sf: The Other Side of Realism (pp. 130-146). Bowling Green: Bowling Green University Popular Press.

Douglas, M. (1992). Risk and blame: Essays in cultural theory. Abingdon: Routledge.

Douglas, M. (2001). Dealing with uncertainty. Ethical Perspectives, 8(3), 145-155.

Edward Snowden SXSW: Full Transcript and Video. (2014, March 10). Inside.com. Retrieved from http://blog.inside.com/blog/2014/3/10/edwardsnowden-sxsw-full-transcription-and-video

Eisenstein, E. L. (1980). The printing press as an agent of change: Communication and cultural transformations in early-modern Europe, volumes I and II. Cambridge: Cambridge University Press.

Eliasoph, N. (1998). Avoiding politics: How Americans produce apathy in everyday. Cambridge: Cambridge University Press.

Ewald, F. (1993). Two infinities of risk. In B. Massumi (Ed.), The Politics of Everyday Fear (pp. 221-228). Minneapolis: University of Minnesota Press.

Fraser, S. (2006). Poetic world-making: Queer as folk, counterpublic speech and the "reader." Sexualities, 9(2), 152-170.

Frosh, P. (2011). Phatic morality: Television and proper distance. International Journal of Cultural Studies, 14(4), 383-400.

Gan, V. (2013, October 24). How TV's "person of interest" helps us understand the surveillance society. Smithsonian.com. Retrieved from http://www. smithsonianmag.com/smithsonian-institution/howtvs-person-of-interest-helps-us-understand-thesurveillance-society-5407171/?no-ist

Giddens, A. (1990). The consequences of modernity. Cambridge: Polity Press;

Goffman, A. (2014). On the run: Fugitive life in an American city. Chicago: University of Chicago Press.

Hannah, M. G. (2010). (Mis)adventures in Rumsfeld space. GeoJournal, 75(4), 397-406.

Hansen, M. (2015). Feed-forward: On the future of twenty-first century media. Chicago: University of Chicago Press.

Hendrix, J. (2013, June 11). NSA surveillance puts George Orwell's "1984" on bestseller lists. Los Angeles Times. Retrieved from http://articles. latimes.com/2013/jun/11/entertainment/la-et-jcnsa-surveillance-puts-george-orwells-1984-onbestseller-lists-20130611

Hong, S. (2014). The other-publics: Mediated othering 
and the public sphere in the Dreyfus Affair. European Journal of Cultural Studies, 17(6), 665-681.

Kelley, M. B. (2013, December 13). NSA: Snowden stole 1.7 million classified documents and still has access to most of them. Business Insider. Retrieved from http://www.businessinsider.com/how-many-docsdid-snowden-take-2013-12

Knappenberger, B. (2013, November 26). Why care about the N.S.A.? New York Times. Retrieved from http://www.nytimes.com/video/opinion/10000000 2571435/why-care-about-the-nsa.html

Knowlton, B. (2013, June 9). Feinstein "open" to hearings on surveillance programs. New York Times. Retrieved from http://thecaucus.blogs.nytimes.com/ 2013/06/09/lawmaker-calls-for-renewed-debateover-patriot-act/?_php=true\&_type=blogs\&_r=0

Lake, E. (2014, February 17). Spy chief: We should've told you we track your calls. The Daily Beast. Retrieved from http://www.thedailybeast.com/ articles/2014/02/17/spy-chief-we-should-ve-toldyou-we-track-your-calls.html

Laskow, S. (2013, July 15). A new film shows how much we knew, pre-Snowden, about Internet surveillance. Columbia Journalism Review. Retrieved from http://www.cjr.org/cloud_control/a_new_film_sho ws_exactly_how_m.php

Leonnig, C. (2013, August 15). Court: Ability to police U.S. spying program limited. The Washington Post. Retrieved from http://www.washingtonpost.com/ politics/court-ability-to-police-us-spying-programlimited/2013/08/15/4a8c8c44-05cd-11e3-a07f49ddc7417125_print.html

Mansell, R. (2012). Imagining the internet: Communication, innovation, and governance. Oxford: Oxford University Press.

Massumi, B. (2005). Fear (the spectrum said). Positions, 13(1), 31-48.

Massumi, B. (2007). Potential politics and the primacy of preemption. Theory \& Event, 10(2).

Merleau-Ponty, M. (2012). Phenomenology of perception. (D. A. Landes, Trans.). London: Routledge.

Milner, M. (2013, June 25). Did Edward Snowden tell us anything we didn't already know? Chicago Reader. Retrieved from http://www.chicagoreader.com/Bleader/archives/2 013/06/25/did-edward-snowden-tell-us-anythingwe-didnt-already-know

Orulv, L., \& Hyden, L.-C. (2006). Confabulation: Sensemaking, self- making and world-making in dementia. Discourse Studies, 8(5), 647-673.

Parks, L. (2007). Points of departure: The culture of US airport screening. Journal of Visual Culture, 6(2), 183-200.

Pearl, S. (2010). About faces: Physiognomy in nineteenth-century Britain. Cambridge: Harvard University Press.

Pfaller, R. (2001). Interpassivity and misdemeanors.
The analysis of ideology and the Zizekian toolbox. International Journal of Zizek Studies, 1(1), 33-50.

Pfaller, R. (2003). Little gestures of disappearance(1) interpassivity and the theory of ritual. Journal of European Psychoanalysis, 16.

Pisters, P. (2013). Art as circuit breaker: Surveillance screens and powers of affect. In B. Pepenburg \& M. Zarzycka (Eds.), Carnal Aesthetics: Transgressive Imagery and Feminist Politics (pp. 198-213). London: I.B. Tauris.

Rainie, L., Kiesler, S., Kang, R., \& Madden, M. (2013, September 5). Anonymity, privacy, and security online. Pew Research Internet Project. Retrieved from http://www.pewinternet.org/2013/09/05/ anonymity-privacy-and-security-online/

Rappaport, R. (1999). Ritual and religion in the making of humanity. Cambridge: Cambridge University Press.

Renkema, L. (2014, December 12). Which VPN services take your anonymity seriously? Torrentfreak. Retrieved from http://torrentfreak.com/which-vpnservices-take-your-anonymity-seriously-2014edition-140315/

Rowan, D. (2014, March 18). Snowden: Big revelations to come, reporting them is not a crime. Wired. Retrieved from http://www.wired.co.uk/news/ archive/2014-03/18/snowden-ted

Scarry, E. (1985). The body in pain: The making and unmaking of the world. Oxford: Oxford University Press.

Scholzel, H. (2014). Beyond interactivity. The interpassive hypotheses on "good life" and communication. Paper presented at International Communication Association 2014, Seattle, USA.

Schouten, P. (2014). Security as controversy: Reassembling security at Amsterdam Airport. Security Dialogue, 45(1), 23-42.

Tarde, G. (1969). On communication and social influence: Selected papers. (T. N. Clark, Ed.). Chicago: University of Chicago Press.

Turner, V. (1982). Liminal to liminoid. In V. Turner (Ed.), Play, Flow, Ritual: An Essay in Comparative Symbology (pp. 53-92). New York: Performing Arts Journal Publishing.

Turow, J. (2013). Branded content, media firms, and data mining: An agenda for research. Paper presented at International Communication Association 2013, London, UK.

Van Buren, P. (2013, January 13). 10 myths about NSA surveillance that need debunking. MotherJones. Retrieved from http://www.motherjones.com/politics/ 2014/01/10-myths-nsa-surveillance-debunk-edwardsnowden-spying

Van Oenen, G. (2002). Interpassivity revisited: A critical and historical reappraisal of interpassive phenomena. International Journal of Zizek Studies, 2(2).

Veyne, P. (1988). Did the Greeks believe in their myths? 
An essay on the constitutive imagination. (P. Wissing, Trans.). Chicago: University of Chicago Press.

Warner, M. (2002). Publics and counterpublics. New York: Zone Books.

We already knew the NSA spies on us. We already know everything. Everything is boring. (2015, February 9). Clickhole. Retrieved from http://www. clickhole.com/article/we-already-knew-nsa-spiesus-we-already-know-every-1876

Whistleblower Edward Snowden gives 2013's alterna- tive Christmas message. (2013, December 25). Channel4.com. Retrieved from http://www. channel4.com/programmes/alternative-christmasmessage/on-demand/58816-001

Wildavsky, A., \& Dake, K. (1990). Theories of risk perception: Who fears what and why? Daedalus, 119(4), 41-60.

Žižek, S. (n.d.). The interpassive subject. Retrieved from http://www.egs.edu/faculty/slavojzizek/articles/the-interpassive-subject

\section{About the Author}

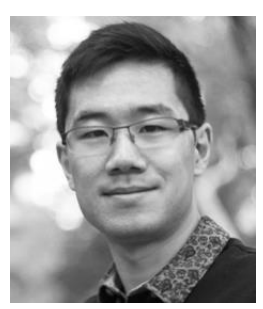

\section{Sun-ha Hong}

Sun-ha Hong is a PhD Candidate at the Annenberg School for Communication, University of Pennsylvania. His current research pursues uncertainty as a world-building resource in the new media society. Surveillance and data-mining's fixation with prediction and simulation show that such worldbuilding involves a constant rearticulation of the unknown and the uncertain. For more, please see: http://sunhahong.org. 